\title{
Influence of Environment-based Learning Materials to Improve the Eco- literacy of PGSD Students
}

\author{
Hana Sakura Putu Arga ${ }^{\bowtie 1}$ \& Galih Dani Septiyan Rahayu² \\ 1,2 Primary School Teacher Education Study Program, IKIP Siliwangi, Cimahi City, Indonesia \\ $\bowtie$ hana-sakura@ikipsiliwangi.ac.id
}

\begin{abstract}
Human concern on the environment is unfortunately seen decreasing, which has resulted in negative environmental damages caused by human actions. To address this issue, this research seeks to see the influence of environment-based teaching materials in social studies learning to improve the eco-literacy of students of primary school teacher education (PGSD, Pendidikan Guru Sekolah Dasar) study program. This research involved third semester 60 PGSD students of a private university in Bandung Regency, Indonesia. Therefore, this research investigated the differences of environment-based learning materials and conventional learning in improving the eco-literacy of PGSD students. This research used a quasi-experimental method with nonrandomized pretest-posttest control group design and used quantitative observation instruments in the form of checklists to obtain the data. The results revealed that by using environment-based learning resources, the social studies learning could improve the eco-literacy of PGSD students, and was considered better than implementing conventional learning.
\end{abstract}

Keywords: eco-literacy, environment-based learning materials, social studies learning, teaching resources

How to Cite: Arga, H. S., \& Rahayu, G. D. (2019). Influence of Environment-based Learning Materials to Improve the Eco-literacy of PGSD Students. Mimbar Sekolah Dasar, 6(2), 208-218. doi:10.17509/mimbarsd.v6i2.17521

INTRODUCTION The era development has been increasingly advanced, and created changes in the social and natural environment. Nowadays, environmental problems are a concern because of various adverse effects on humans. Aziz (2013) explains that environmental problems are considered less important in developing countries compared to developed countries due to their different cases and causes. The main cause of environmental problems in Indonesia is sadly dominated by human behavior. If these problems are not immediately addressed, it will have a negative effect on life sustainability. Therefore, it needs support from various parties including the education sector to overcome these problems. Education serves to educate people who have caring attitudes for the environment. Supriatna (2016) explains that education is able to significantly change the mindset of people's behaviour. Someone will understand better on behaving well towards nature through education, so that they will think before they act. The research focuses on the eco-literacy of the PGSD students in one of the universities in Cimahi City to provide a solution to the environmental problems. Boehnert (2015) explains that eco-literacy is indispensable in 
Hana Sakura Putu Arga \& Galih Dani Septiyan Rahayu, Influence of Environment-Based Learning...

educational programs to illustrate the strong relationships between human life and the earth in its relation to the fields of education, politics, social and economics in designing sustainable lifestyles. Therefore, based on the understanding of the eco-literacy of students, they are expected to get used to implement ecoliteracy-based learning by utilizing various teaching resources in the learning process. According to Zulfa, Max, Hukum, \& llyas (2015), the understanding of critical environmental problems can be one of the efforts to change students' behavior, hence, it is expected that the students will possess caring attitudes and awareness for the environment. Therefore, in attempting to provide eco-literacy learning, the teachers are required to understand the implementation of the concept of the caring attitudes for the environment, thus it is expected that the role of the teacher will provide improvements to the future movement.

According to Carlson, Heimlich, \& Storksdieck (n.d.) and Keraf (2014), ecoliteracy is defined as a situation where people are enlightened about the importance of the environment. Someone who already has an understanding of ecoliteracy will tend to think before she/he acts in relation to behavior that can damage the environment due to the awareness of a reciprocal relationship between humans and nature. According to Goleman \& Barlow (2012), the indicators of the eco-literacy must be developed to create a society that has ecological literacy, namely:

1. Developing empathy for all forms of life

2. Embracing sustainability as a community practice)

3. Making the invisible visible

4. Anticipating the unintended
consequences

5. Understanding how nature sustains life

From some of these explanations, it is necessary to increase the number of prospective primary school educators in utilizing environment-based teaching resources. In the research conducted by Lustanti (2013) entitled "Utilization of the Surrounding Environment to Improve Learning Outcomes at Primary School Science Lessons", it revealed that the implementation of learning by utilizing the environment as a teaching resource had an effect on the teacher activeness in helping the students' learning process by providing knowledge and understanding in caring for the environment. Environmental awareness can be grown within students if the teacher has ecoliteracy (Rusmawan, 2017). In line with Carlson et al. (n.d.); Kochlar (n.d.); and McBeth, (2009), the best practice for environmental education is to experience it in the field, as one of the informal education about the environment, children should learn through activities. 
The environment-based teaching resources referred to this research are as follows:

\section{Resources for teaching the school} environment. By utilizing the school environment, students will be able to compile materials that are obtained from school environment. In specific, the students are assigned to observe nature and environmental problems existed in the school, then discuss and find the solutions to solve the problems.

\section{Community environmental teaching} resources. By utilizing the community environment, students will be able to compile materials obtained from the community environment. In specific, the students are assigned to observe social problems related to the surrounding environment, and discussing solutions.

\section{Learning resources based on the} natural environment. By utilizing natural environment, students will be able to enhance their creativity. For example, assigning students to make traditional toys from natural materials, so that students can increase their interest in creating other traditional crafts/toys, such as puppets from cassava leaves and toy cars from orange peel.

\section{Environmental-based game resources.}

By utilizing the game environment, teachers can integrate traditional games to provide meaningful activity for students without using gadgets.
The utilization of environment as a teaching resource in social studies learning is expected to provide a direct ecoliteracy-based learning for PGSD students in one of the universities in Cimahi City.

In specific, it is expected to provide meaningful experiences for students, so that they will be able to directly apply the eco-literacy attitude in the learning process in their surrounding environment. McBeth \& Volk (2009) reveal that the implementation of ecological behavior is more difficult than having ecological knowledge. It is considered important for individuals to show ecological behavior in daily interactions with the society. In relation to this issue, the role of the creative intuition of prospective educators can influence the achievement of learning objectives.

Therefore, there is an effort to improve the creativity of prospective educators in creating teaching resources that are able to provide meaningful learning for the students. The implementation of environment-based teaching resources to improve the students' eco-literacy at one of the universities in Cimahi City was inspired by some previous studies. Arga (2018) regarding the application of project-based learning models to improve the eco-literacy of primary school students through urban farming activities. His study revealed that the application of the PPA (Product Purchase Agreement) model in making urban farming could increase the eco-literacy of students in social studies 
Hana Sakura Putu Arga \& Galih Dani Septiyan Rahayu, Influence of Environment-Based Learning...

learning. Besides, a research conducted by Nugraha (2016) regarding the application of field trip models to improve the eco-literacy of students in economic activities in social studies learning revealed that there was a significant increase in the eco-literacy of the students after conducting learning outside class.

Based on previous studies, there is a gap in terms of substance, since it has not been found research focusing on the improvement of prospective student educators' teaching ability by utilizing the environment as social science teaching resources in order to be able to increase the eco-literacy, since those previous studies focus on increasing eco-literacy learners. Therefore, the formulation of this study are: 1) How is the influence of learning by utilizing the environment as a social science teaching resource on the eco-literacy of PGSD students in the experimental class ?; 2) How is the influence of conventional learning with the environment as a social science teaching resource on the eco-literacy of PGSD students?; 3) How is the comparison of the increase in eco-literacy between students in the class that apply learning by utilizing the environment as a teaching resource and students in the class that apply conventional learning. The research objectives are in accordance with the formulation, which are 1) to determine the effect of learning by utilizing the environment as a social science teaching resource on the eco-literacy of PGSD students in the experimental class; 2) to determine the effect of conventional learning on the eco-literacy of PGSD students in the control class; 3 ) to compare the increase in the eco-literacy of PGSD students in a class using learning by utilizing the environment as an social science teaching resource, and PGSD students in a class using conventional learning. Based on these problems, the increase in the eco-literacy of PGSD students by utilizing the environment as a social science teaching resource is strictly necessary to carry out. Therefore, the research is titled "influence of environment-based learning materials to improve the eco-literacy of PGSD students".

\section{METHOD}

This research employs a quasiexperimental method with a nonrandomized pretest-posttest control group design. According to Levy \& Ellis (2011) and Sugiyono (2011; 2013), the nonrandomized pretest-posttest control group design is described as follows.

Table 1. The nonrandomized pretestposttest control group design.

\begin{tabular}{llll}
\hline Class & Pretest & Treatment & Posttest \\
\hline Experimental & $O$ & $X_{1}$ & $O$ \\
\hline Control & $O$ & $X_{2}$ & $O$ \\
\hline
\end{tabular}

Information:

$0=$ Pretest-posttest eco-literacy

$\mathrm{X} 1=$ Learning in the experimental class

$\mathrm{X} 2=$ Learning in the control class 
The research procedure consisted of four stages, namely planning stage, implementation stage, final stage, and publication stage. The planning stage comprised (1) analyzing the results of previous studies on the eco-literacy of PGSD students, (2) analyzing the development of social studies learning using teaching resources, (3) compiling learning using environment-based teaching resources, (4) compiling validating and testing instruments. The implementation stage comprised 1) conducting the pretest, (2) carrying out learning using environment-based teaching resources in the experimental class, and conventional learning in the control class, (3) conducting the posttest. The final stage comprised (1) collecting data on the research results, (2) processing and analyzing the research results, and (3) preparing the research reports. The publication stage comprised publishing the research results in the forms of research reports.

This research was conducted in one of the universities in Cimahi City. The population of this research was all PGSD students, by involving the third-semester PGSD students in two classes with 60 students as the samples, which were homogeneous in terms of class culture and the average scores of social studies in primary school. The third semester students were chosen as the research instruments, because at the time, they were taking an internship program in teaching social studies.
Therefore, it is believed that this can provide benefits for students to learn using teaching resources with eco-literacy indicators. The instruments were compiled and validated by experts and PGSD students, so that the instrument was considered valid. Furthermore, the data were obtained from the instrument used in the pretest and posttest, then the data were processed and analyzed by the assistance of SPPs 20 applications.

\section{RESULTS}

The research results revealed that there was a significant increase in the ecoliteracy of PGSD students in the experimental class. These were obtained from the data processing and analysis using the SPSS 20 application, as depicted in Graph 1.

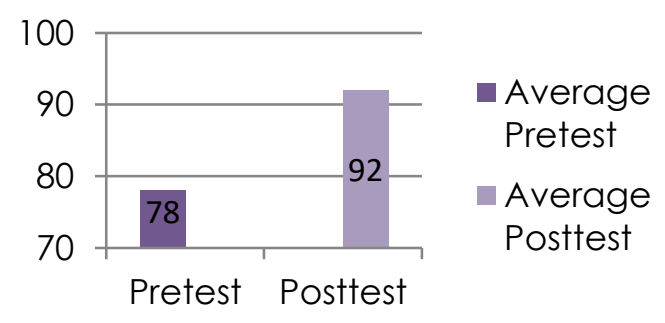

Graph 1. Average score of PGSD students in an experimental class.

The processing results using t-test statistics obtained by sig data. (2-tailed) was 0.000 $<0.05$, it indicated that there was a significant increase in the eco-literacy of PGSD students in the experimental class. Ttest was conducted because the data was not normally distributed. The processing results are presented in Table 2. 
Hana Sakura Putu Arga \& Galih Dani Septiyan Rahayu, Influence of Environment-Based Learning...

Table 2. Results of eco-literacy test in the experimental class.

\begin{tabular}{|c|c|c|c|}
\hline $\begin{array}{l}\text { T-test in } \\
\text { Experimental } \\
\text { Class }\end{array}$ & $\begin{array}{l}\text { Sig. }(2- \\
\text { tailed) }\end{array}$ & Significance & Information \\
\hline \multicolumn{4}{|l|}{ Pretest } \\
\hline \multicolumn{4}{|l|}{ Posttest } \\
\hline \multicolumn{4}{|c|}{$\begin{array}{l}\text { Moreover, the research results also } \\
\text { revealed that there was an increase in the }\end{array}$} \\
\hline \multicolumn{4}{|c|}{ eco-literacy of PGSD students using } \\
\hline \multicolumn{4}{|c|}{ conventional learning in the control class. } \\
\hline \multicolumn{4}{|c|}{ These were obtained through the data } \\
\hline \multicolumn{4}{|c|}{ processing and analyzing using the SPSS 20} \\
\hline \multicolumn{4}{|c|}{ application as depicted in Graph 2 and its } \\
\hline \multicolumn{4}{|c|}{ processing result is depicted in Table 3.} \\
\hline \multicolumn{4}{|l|}{86} \\
\hline \multicolumn{4}{|l|}{84} \\
\hline \multicolumn{4}{|l|}{82} \\
\hline \multicolumn{4}{|l|}{80} \\
\hline 78 & & & Average \\
\hline 76 & & & \\
\hline & & Posttest & \\
\hline
\end{tabular}

Graph 2. Average score of PGSD students is the control class.

Table 3. Results of eco-literacy in the control class.

\begin{tabular}{lccc}
\hline $\begin{array}{l}\text { t-Test in } \\
\text { Control Class }\end{array}$ & $\begin{array}{l}\text { Sig.(2- } \\
\text { tailed) }\end{array}$ & Significance & Information \\
\cline { 1 - 3 } Experimental & 0.0. & 0.05 & Improved \\
\cline { 1 - 1 } Control & 023 & & \\
\hline
\end{tabular}

The results obtained showed that the ecoliteracy of students in the experimental class experienced a more significant increase than students in the control class as depicted in Graph 3 below.

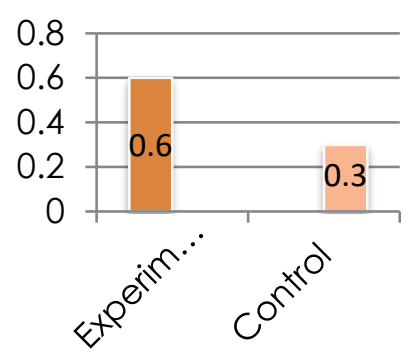

- Average $\mathrm{N}$-gain

Average $\mathrm{N}$ gain

Graph 3. Average N-gain of the eco-

literacy of students.

The results of statistical processing using ttest for $\mathrm{N}$-gain score between the experimental class and the control class are presented in Table 4.

Table 4. Result of t-Test for $\mathrm{N}$-gain Score of eco-literacy.

\begin{tabular}{|c|c|c|c|}
\hline N-gain test & $\begin{array}{l}\text { Sig.(2- } \\
\text { tailed) }\end{array}$ & Significance & Information \\
\hline Experimental & & & \multirow[b]{2}{*}{$\begin{array}{l}\text { There are } \\
\text { differences in } \\
\text { improvement }\end{array}$} \\
\hline Control & 0.012 & 0.05 & \\
\hline
\end{tabular}

\section{DISCUSSION}

\section{Learning in the experimental class}

In the experimental class, the thirdsemester PGSD students of A-class utilized the environment as a teaching resource in primary schools' social studies during their internship learning courses. In the learning process, these students were divided into several groups in the first meeting, and they were given the assignments to make teaching materials by utilizing the environment as a social science teaching resource. In each student group, they carried out several activities by utilizing natural environments, such as conducting environmental observations, making observational reports, making teaching 
materials based on environmental waste, making traditional toys using natural materials, making traditional games for learning outside classrooms, so that students were getting more active and happy to learn. After developing these teaching materials, they used them in their class. According to Istialina (2016). primary school teachers must be able to develop critical and reasoning abilities through various pedagogical technique. Therefore, they were required to conduct various researches and innovations in solving problems occurred in the teaching and learning process. In the learning process, there was an interesting finding indicating that the students had difficulty in determining the appropriate teaching materials to be applied in learning outside classroom by utilizing the natural environment. This problem was caused by the students' inability to make teaching materials for learning outside classroom, so that they still felt awkward. The problem of student learning activities was an important problem that needed to be resolved (Hanik, Harsono, \& Wiharti, 2016). Therefore, a re-evaluation was needed to improve the learning process in the future.

In the next meeting, the students had been getting used to carrying out a learning using eco-literacy-based teaching materials, thus the researchers then conducted evaluations, and analyzed the preparations for the second learning process. In the second learning process, there was an interesting finding revealing that each group had been able to discuss interestingly and actively in making teaching materials by using the environment as a teaching resource. and ready to present the application of environment-based teaching materials. There were many teaching materials presented by the students, such as applying the research-based teaching materials in observing the natural environment, applying teaching materials by making waste processing projects, applying the learning about making traditional toys using plants, applying the learning about making traditional games to for learning outside classroom. The results revealed that there was a better improvement in the learning by utilizing the environment as a social science teaching resource, it resulted in an increase in the eco-literacy of PGSD students.

\section{Learning in the control class}

Learning in the control class was carried out by the third-semester PGSD students of B-class applying conventional learning, which was a learning using group presentation method with the media of PowerPoint and papers regarding the environment as social science teaching resources. In the learning process, there were some interesting findings, e.g., lack of readiness of students in presenting the eco-literacy materials of the use of the environment as a resource, which indicated by the less interesting PowerPoint presentations, hence other students were not interested in paying 
Hana Sakura Putu Arga \& Galih Dani Septiyan Rahayu, Influence of Environment-Based Learning...

attention to the presentations. These problems could be caused by internal factors and external factors (Placeholder1). According to Ghavifekr, Kunjappan, Ramasamy, \& Anthony (2016), learning difficulties of students was mainly affected by the ability of the students. In addition, these difficulties were also affected by learning motivation, attention, and interest; attitudes in learning; perseverance; and socio-economic, physical and psychological factors. External factors could be affected by the teacher and the environment. In this first meeting, these difficulties made students less creative in making environment-based teaching materials. so that, the evaluation and improvements were needed.

In the second meeting, the learning process was carried out more maximally than in the first meeting, Uno (2008) explains that to improve the quality of learning should start with an improvement in learning design. Learning planning was the main step to improve the quality of learning because it would be arranged learning steps systematically. In the second meeting of the previous learning method was still used, but the students who had an occasion to present with their group were required to make interesting PowerPoint as teaching media with environment-based material in the social study subject. These forms of presentation were expected to help the speakers in delivering their material better, thus other students were able to understand it. According to
Carlson et al. (n.d.), Environmental Field Day (EFD) was introduced as a series of events held throughout the country with the purposes of providing a unique opportunity to involve students in real world science. The study of the validity of the observation tool for EFD programs was conducted at the Metro Water Festival which participated by the fifth-grade students. In the study, items from the observation tool was mapped to students' evaluation questions to determine the degree to which observed characteristics of the field day are aligned with student perception. The data are in line with the conclusion in which the observation tool did not only capture the perspective of a trained observer on the educational potential of a field day, but also the perceived experience of the field day audience (the students), despite the fact that the observation tool was designed to capture an expert perspective on effective pedagogy and educational practice (Munadi, 2008). Faelasofi (2015) explains that the main function of learning media is as a source of learning. The optimization of the use of Microsoft PowerPoint as one of the learning media was able to be used as a support in conventional learning. In the second meeting, the findings revealed that there was an increase in the eco-literacy of PGSD students in utilizing the environment as a teaching resource. The results showed a positive results indicated from the increase in the eco-literacy of students compared to the pretest results, 
nevertheless, there were still some students who were still less enthusiastic in the learning process.

Based on the results, this research was expected to provide implications, such as (1) a learning using environment-based teaching resources was able to increase the eco-literacy of PGSD students in primary school social studies; (2) a learning using the environment as social science teaching resources was able to improve PGSD students' ability to make ecoliteracy-based social science teaching materials for primary school students; 3) Social studies learning by utilizing the environment as a social science teaching resource was able to improve the creativity of PGSD students in developing natural teaching media in the learning outside classroom, so that student could actively participate in the learning process.

\section{CONCLUSION}

Based on the aforementioned research results and findings of the research, the conclusion of this research was 1) a learning by utilizing the environment as a social science teaching resource was able to increase the eco-literacy of PGSD students; 2) a learning by utilizing the environment as an social science teaching resource was better than conventional learning; 3 ) the maximum planning process was needed for the learning implementation, hence it was able to provide opportunities for students to develop creativity in creating meaningful environment-based teaching materials.

\section{RECOMMENDATION}

Through this research, prospective educators are able to develop in-depth research by creating innovations in the utilization of the environment as a social science teaching resource. For example, the further research that can be conducted by prospective educators in utilizing the environment as a teaching resource is making traditional puppets using the basic materials of cassava plants, so that students are able to develop their creativity, and provide valuable experiences in the learning process. The followings are the proposed steps that educator can implement in utilizing the plantation environment for making traditional toys:

1. Discussing various traditional culture existed in Indonesia, one of which is puppets, with the students.

2. Making a prepared learning plan by inviting students to the nearest cassava plantation, or observing the back gardens planted with cassava, if it is not possible, the educators can look for alternatives by visiting the closest cassava plantations for the students' observation.

3. Inviting the students to visit cassava plantations, and forming groups to make observations, and a puppet project made of cassava. 
Hana Sakura Putu Arga \& Galih Dani Septiyan Rahayu, Influence of Environment-Based Learning...

4. Explaining the steps for making puppets using leaves and cassava stems.

5. Asking the students to answer students' worksheets and observation sheets.

6. Inviting the students to present the results of the puppets' work made by the group of students, and to explain the results of the students' observations.

In addition to conducting this research, it is expected that there will be more researchers able to develop other learning methods with the use of environmentbased teaching resources to provide meaningful learning to students in learning social science in primary schools.

\section{ACKNOWLEDGMENT}

Gratitude is extended to the Directorate General of Research and Development Reinforcement of Ministry of Research, Technology and Higher Education who has provided the funds to conduct the research through a research program for beginner lecturers, thus this research could be conducted properly in accordance with its targets and objectives.

\section{REFERENCES}

Aziz, E. (2013). Upaya pelestarian lingkungan hidup melalui pendidikan Islam. Yogyakarta: Pustaka belajar.

Boehnert, J. (2015). Ecological Literacy in Design Education - A Theoretical Introduction. FORMakademisk, 8(1). https://doi.org/10.7577/formakademis k.1405

Carlson, S. P., Heimlich, J. E., \& Storksdieck, M. (n.d.). Validating an Environmental Education Field Day Observation Tool. 16.

Faelasofi, R. (2015). Penggunaan Media Pembelajaran Microsoft Office
Powerpoint pada Pokok Bahasan Peluang. 1 (1), 13.

Ghavifekr, S., Kunjappan, T., Ramasamy, L., \& Anthony, A. (2016). Teaching and Learning with ICT Tools: Issues and Challenges from Teachers' Perceptions. 4 (2), 20.

Goleman, D., \& Barlow, Z. (2012). Ecoliterate: How Educators are Cultivating Emotional, Social an Ecological Intelligence. Jossey Bass. A Wiley Imprint. USA Healdsburg, CA: Watershed Media.

Hanik, N. R., Harsono, S., \& Wiharti, T. (2016). Peningkatan Aktivitas dan Prestasi Belajar Mahasiswa Melalui Pemberian Post Test pada Mata Kuliah Telaah Kurikulum Dan Perangkat Pembelajaran Biologi Sekolah Menengah Atas dengan Pendekatan Terpadu. Jurnal Edukasi Matematika dan Sains, $4(1), \quad 1$. https://doi.org/10.25273/jems.v4i1.198

Istialina, I. (2016). Pemanfaatan lingkungan sebagai sumber belajar pada subtema hewan dan tumbuhan di lingkungan rumahku kelas IV SD Negeri 3 Jeumpa. Jurnal Ilmiah Mahasiswa Prodi PGSD, 1 (1).

Keraf, S. A. (2014). Filsafat Lingkungan Hidup, Alam sebagai Sebuah Sistem Kehidupan (bersama Fritjop Capra). Yogyakarta: Kanisius.

Kochlar, S. K. (n.d.). Methods and techniques of teaching. Sterling Publishers PVT, Ltd.

Levy, Y., \& Ellis. T, J. (2011). A Guide for Novice Researchers on Experimental and Quasi-Experimental Studies in Information Systems Research. Interdisciplinary Journal of Information, Knowledge, and Management, 6(1), 151-161.

Lustanti, R. K. (2013). Pengaruh hands on activity terhadap kemampuan membaca permulaan siswa kelas satu sekolah dasar. JPGSD, 1 (2), 1-10.

McBeth, W., \& Volk, T. L. (2009). The National Environmental Literacy Project: A Baseline Study of Middle Grade Students in the United States. The Journal of Environmental Education, $\quad 41(1)$, 55-67. https://doi.org/10.1080/0095896090321 0031

Munadi, Y. (2008). Media Pembelajaran. Ciputat: Gaung Persada (GP) Press. 
Nugraha, R. G. (2016). Meningkatkan Ecoliteracy Siswa SD Melalui Metode Field-Trip Kegiatan Ekonomi pada Mata Pelajaran IImu Pengetahuan Sosial. Mimbar Sekolah Dasar, 2(1). https://doi.org/10.17509/mimbarsd.v2il.1322

Putu Arga, H. S. (2018). Application of Project Based Learning Models to Improve Ecoliteracy of Elementary School Students through Urban Farming Activities. PrimaryEdu Journal of Primary Education, 2(2), 95. https://doi.org/10.22460/pej.v2i2.1014

Rusmawan, R. (2017). Eco-literacy Dalam Konteks Pendidikan IPS. SOSIO DIDAKTIKA: Social Science Education Journal, 4 (2).

Sugiyono, S. (2013). Metode Penelitian Pendidikan Pendekatan Kuantitatif, Kualitatif, dan R\&D. Bandung: Alfabeta.

Supriatna, N. (2016). Ecopedagogy: Membangun Kecerdasan Ekologis dalam Pembelajaran IPS. Bandung: PT Remaja Rosdakarya.

Uno, H. (2008). Perencanaan Pembelajaran. Jakarta: PT. Bumi Aksara.

Zulfa, V., Max, M., Hukum, I., \& llyas, I. (2015). Isu-Isu Kritis Lingkungan dan Perspektif Global. Jurnal Green Growth dan Manajemen Lingkungan, 5(1). 29-40. https://doi.org/10.21009/jgg.051.03 